Ambiente \& Água - An Interdisciplinary Journal of Applied Science
ISSN 1980-993X - doi:10.4136/1980-993X
www.ambi-agua.net
E-mail: ambi.agua@gmail.com

\title{
Enzymes from kidney, gill and brain tissues of Astyanax bimaculatus (lambari) as biomarkers of environmental impact in the Una River basin
}

\author{
doi:10.4136/ambi-agua.2314
}

Received: 18 Nov. 2019; Accepted: 18 Dec. 2019

\begin{abstract}
Maria Tereza Oliveira Batista ${ }^{1}$; Marilia Elias de Almeida ${ }^{2,3}$; Gannabathula Sree Vani1 ${ }^{1}$; Mariana Feijó de Oliveira ${ }^{4}$; Edson Rodrigues' ${ }^{1}$ Cecilia Nahomi Kawagoe Suda ${ }^{1,4^{*}}$

${ }^{1}$ Programa de Pós-graduação em Ciências Ambientais. Universidade de Taubaté (UNITAU), Rua Visconde do Rio Branco, 210, CEP 12020-240, Taubaté, SP, Brazil. E-mail: contato.maria.tereza@gmail.com, gannabathulasreevani@gmail.com, rodedson@gmail.com

${ }^{2}$ Departamento de Biologia. Universidade de Taubaté (UNITAU), Av. Tiradentes, 500, CEP 12030-180,

Taubaté, SP, Brazil. E-mail: mariliabiodmais@gmail.com

${ }^{3}$ Departamento de Enfermagem Materno-Infantil e Saúde Pública. Escola de Enfermagem de Ribeirão Preto.

Universidade de São Paulo (USP), R. Prof. Hélio Lourenço, 3900, CEP 14040-902, Ribeirão Preto, SP, Brazil.

E-mail: mariliabiodmais@gmail.com

${ }^{4}$ Instituto Básico de Biociências, Universidade de Taubaté (UNITAU), Av. Tiradentes, 500, CEP 12030-180,

Taubaté, SP, Brazil. E-mail: marifeijo.bio@gmail.com

*Corresponding author. E-mail: cnksuda@hotmail.com
\end{abstract}

\section{ABSTRACT}

The Una River and its basin constitute an important water source for public supply in the municipality of Taubaté (SP, Brazil). The present work aimed to investigate biochemical markers of environmental pollution in the Una river basin using enzymes extracted from the kidneys, gills and brains of Astyanax bimaculatus, a fish commonly found in this basin. Tissue levels of superoxide dismutase (SOD), catalase (CAT), malate dehydrogenase (MDH), lactate dehydrogenase $(\mathrm{LDH})$ and acetylcholinesterase $(\mathrm{AChE})$ were determined in tissues of $A$. bimaculatus collected in water bodies localized at Fazenda Piloto of the University of Taubaté (P1), the Remédios municipal road (P2) and at a small lake near the neighborhood of Ipiranga (P3), all located in the municipality of Taubaté. The lowest activities of renal and gill SOD were found in fish collected from P2 and P3, respectively. Renal and branchial CAT, renal MDH and $\mathrm{LDH}$, as well as the activity of cerebral LDH were not affected by collection site. The activities of brain MDH and AChE were higher in fish from P3 in comparison with P1. These results along with earlier published findings, indicate that the hepatic SOD and CAT, gill SOD and $\mathrm{LDH}$, muscle $\mathrm{MDH}$ and brain $\mathrm{MDH}$ and $\mathrm{AChE}$ are sensitive to contamination in the environment and hence can be considered as good candidate biomarkers of environmental change in the Una River basin.

Keywords: biomarker, enzymes, water pollution.

\section{Enzimas dos tecidos renal, branquial e cerebral de Astyanax bimaculatus (lambari) como biomarcadoras do impacto ambiental na Bacia Hidrográfica do Rio Una}

\section{RESUMO}

$\mathrm{O}$ rio Una e sua bacia hidrográfica constituem importante fonte de água para o

(c) (1)


abastecimento público no município de Taubaté (SP, Brasil). O presente trabalho teve como objetivo investigar marcadores bioquímicos de poluição ambiental da Bacia Hidrográfica do Rio Una, utilizando-se enzimas extraídas dos rins, brânquias e cérebro de Astyanax bimaculatus, um peixe comumente encontrado nessa bacia. Níveis teciduais das enzimas superóxido dismutase (SOD), catalase (CAT), malato desidrogenase (MDH), lactato desidrogenase $(\mathrm{LDH})$ e acetilcolinesterase (AChE) foram determinados em A. bimaculatus coletados em corpos d'água localizados na Fazenda Piloto da Universidade de Taubaté (P1), Estrada Municipal de Remédios (P2) e numa pequena lagoa próxima ao bairro Ipiranga (P3), todos localizados no município de Taubaté. Os níveis de atividade de SOD dos tecidos renal e branquial foram os mais baixos nos peixes provenientes de $\mathrm{P} 2$ e $\mathrm{P} 3$, respectivamente. As atividades de CAT renal e branquial e de MDH e LDH renais não foram afetadas pelo local de coleta, bem como a atividade de LDH cerebral. Os níveis de atividade de $\mathrm{MDH}$ e de AChE cerebrais foram maiores nos peixes provenientes de P3 em comparação com os de P1. Esses resultados, juntamente com os dados publicados anteriormente, indicaram que SOD e CAT hepáticos, SOD e LDH branquial, MDH muscular e MDH e AChE cerebrais foram sensíveis à contaminação ambiental, podendo ser utilizados como marcadores bioquímicos de alteração ambiental na bacia do rio Una.

Palavras-chave: biomarcador, enzimas, poluição da água.

\section{INTRODUCTION}

Early detection of environmental pollution is important because by the time the alteration in the environment is evident, it may be too late to take corrective action, or it may be economically infeasible. Biomarkers could be used for early detection of sublethal levels of pollutants. Since fish live their entire life cycle in water, their cellular enzymes are considered good biomarkers for monitoring water quality. Enzymes may be classified as biomarkers of exposure, that are defined as "markers which indicate an early biochemical response has occurred following exposure of an individual or organism to a contaminant" (Kroon et al., 2017). Frequently used biochemical markers are antioxidative enzymes such as catalase (CAT) and superoxide dismutase (SOD), enzymes that are related to energy metabolism such as lactate dehydrogenase (LDH) and malate dehydrogenase (MDH) and enzymes related to neurotransmission such as acetylcholinesterase (AChE) (Kumar et al., 2017).

SOD is the first line of defense against oxidative stress and converts superoxide radicals into hydrogen peroxide, whereas CAT converts hydrogen peroxide into water and oxygen. LDH catalyzes the reversible reaction between pyruvate and lactate coupled with oxidation-reduction of NADH-NAD ${ }^{+}$and is considered an indicator of anaerobic capacity of the cell. MDH catalyzes the reversible oxidation of malate into oxaloacetate, using NAD as a co-factor. There are cytosolic and mitochondrial isoforms of MDHs and they participate in the malate-aspartate shuttle system, Krebs cycle, and malate-oxaloacetate interconversion during gluconeogenesis and lipogenesis-related reactions (Nelson and Cox, 2014). AChE is a serine hydrolase that converts acetylcholine into acetate and choline for termination of nerve impulse transmission, and is essential to normal behavior and muscular function (Čolović et al., 2013). AChE has been used as a specific biomarker for pesticides, and cerebral AChE of the fish Poecila reticulate showed dose-dependent inhibition by chlorpyrifos, an organophosphate insecticide (Deb and Das, 2013).

The Una River basin occupies $442.85 \mathrm{~km}^{2}$, and $84 \%$ of this area is in the municipality of Taubaté (São Paulo state). Its main river, Una, is used as a water source for public supply of drinking water and for farming activity in this municipality. The Una river is also one of the important tributaries of the Paraíba do Sul river, whose waters run through the states of São

Rev. Ambient. Água vol. 7 (supplement) - Taubaté 2019 
Paulo, Minas Gerais and Rio de Janeiro (Una River Basin Environmental Database http://www.agro.unitau.br/una).

Astyanax aff. bimaculatus (locally called lambari-do-rabo-amarelo) is the most abundant species of the Una river. It is a small fish with a high reproduction rate and rapid growth. The fish feeds on zooplankton, detritus, higher plants and sometimes fish scales, being an opportunistic feeder (Honorio and Martins, 2018). Levels of enzymatic activity of SOD and CAT of liver, and MDH and LDH of hepatic, muscular and branchial tissues of A. bimaculatus were previously investigated as candidate biomarkers of environmental changes in the Una River basin (Batista et al., 2014; Ribeiro et al., 2015; de Almeida et al., 2016). In this context, this work investigated the activity of SOD and CAT of renal and branchial tissues, MDH and LDH of renal and cerebral tissues, as well as brain AChE of A. bimaculatus. The aim was to show which enzymes from these tissues are suitable candidates as biochemical markers of pollutants in the Una River basin. We also compared present and previous published results.

\section{MATERIALS AND METHODS}

\subsection{Sample collection}

The fish collection sites were: (1) Fazenda Piloto (P1) in the Itaim stream located on the property of Fazenda Piloto (an experimental farm) of the University of Taubate (S $23^{\circ} 01^{\prime} 38.3^{\prime \prime}$ W 45'30'31.6"); (2) Remédios (P2), a stream which flows to the Una River, located along the Remédios municipal road (S $23^{\circ} 03$ '26.4" W 45 30'23.5”), close to rice cultivation; (3) Ipiranga (P3), a lake near a pasture for cattle and close to the Dr. José Luiz Cembranelli municipal road (23 01 '49.4" S and 45'30'16.7' W). The map of sampling sites was published in previous studies (Batista et al., 2014; Ribeiro et al., 2015). The specimen sampling was approved by MMA - SISBIO (authorization No. 41097-1) and by the Committee for Ethics in Animal Research of the University of Taubate (CEUA/UNITAU, No. 013/2013). The specimens of the fish Astyanax bimaculatus were collected at each of the three locations between December 2013 and March 2014. A size 20 nylon fishing net, as well as line and hook were used for collection as described by Batista et al. (2014) and Ribeiro et al. (2015). The fish were anesthetized with benzocaine $0.1 \%$, dissected on an ice tray, and the tissues were stored at $-86^{\circ} \mathrm{C}$ for further analysis.

\subsection{Biochemical analysis}

\subsubsection{SOD, CAT, MDH and LDH extraction from kidney and brain.}

The tissues were homogenized in a Potter-Elvehjen homogenizer, in the proportion 1:5 $(\mathrm{w} / \mathrm{v})$ of tissue in $50 \mathrm{mM}$ Tris- $\mathrm{HCl}$ buffer $(\mathrm{pH}$ 7.4). The subcellular structures were broken down with a sonic dismembrator (Model 100, Fisher Scientific) and then centrifuged at 14,000 $\mathrm{x} \mathrm{g}\left(5810 \mathrm{R}\right.$, Eppendorf) for 10 minutes at $4^{\circ} \mathrm{C}$, and the supernatant was used for biochemical analysis.

\subsubsection{SOD and CAT activities}

SOD activity was determined using a reaction system containing $100 \mathrm{mM}$ sodium carbonate buffer (pH 10.2), 17.5 $\mu \mathrm{M}$ EDTA and $1 \mathrm{mM}$ NBT (nitrotetrazolium blue chloride). The reaction was initiated by the addition of hydroxylamine for a final concentration of 3.7 $\mathrm{mM}$. The increase in absorbance was measured at $\lambda=560 \mathrm{~nm}$ by a microplate reader (Fluorstar Optima, BMG Labtech) (Kono, 1978). One unit of SOD was expressed as a quantity of enzyme that inhibited $50 \%$ of NBT reduction. CAT activity was determined in a reaction system containing $100 \mathrm{mM}$ sodium phosphate buffer ( $\mathrm{pH} 7.0$ ), and $12 \mathrm{mM}^{\circ} \mathrm{H}_{2} \mathrm{O}_{2}$. The reduction in absorbance was determined at $\lambda=240 \mathrm{~nm}$ (spectrophotometer DU 640, Beckman) (Regoli et al., 1997). The total protein concentration was determined by the bicinchoninic acid method (BCA) using the Sigma-Aldrich reagent kit and bovine albumin serum as a standard (Smith et al., 
1985). CAT activity is expressed in International Units (U), indicating the quantity of substrate in $\mu \mathrm{mol}$ transformed into product per minute $\left(\mu \mathrm{mol} \mathrm{min} \mathrm{m}^{-1}\right)$ and normalized as a function of the total protein concentration in the homogenate ( $\mu \mathrm{mol} \mathrm{min}^{-1} \mathrm{mg}^{-1}$ protein; U/mg protein).

\subsubsection{MDH and LDH activities from kidney}

$\mathrm{MDH}$ activity was determined by mixing the supernatant with $50 \mathrm{mM}$ Tris- $\mathrm{HCl}$ buffer $(\mathrm{pH}$ 7.4), containing $0.4 \mathrm{mM}$ oxaloacetate, $20 \mathrm{mM} \mathrm{MgCl} 2$ and $150 \mu \mathrm{M} \mathrm{NADH}$ (Childress and Somero, 1979). For LDH activity the supernatant was mixed with $50 \mathrm{mM}$ Tris-HCl buffer (pH 7.4), containing $1 \mathrm{mM}$ sodium pyruvate, $100 \mathrm{mM} \mathrm{KCl}$, and $250 \mu \mathrm{M} \mathrm{NADH}$ (Thuesen et al., 2005). The reaction velocity was determined by a decrease in absorbance at $340 \mathrm{~nm}(\varepsilon=6.22$ $\mathrm{mM}^{-1} \mathrm{~cm}^{-1}$ ) resulting from the oxidation of $\mathrm{NADH}$. The temperature was maintained at $25^{\circ} \mathrm{C}$ by the Peltier system and absorbance was read using a Beckman DU640 spectrophotometer. The activities of MDH and LDH were expressed in $\mu \mathrm{mol}$ of substrate transformed into product per minute (U). Activities were calculated as a function of total protein concentration and expressed as $\mathrm{U} \mathrm{mg}^{-1}$ protein. Total protein was determined by the Bradford method (1976) using bovine serum albumin (BSA) as standard.

\subsubsection{MDH and $\mathrm{LDH}$ activities from brain tissue}

The same methods described above for MDH and LDH from kidney tissue were used for brain tissue. However, the spectrophotometer Jenway $6715 \mathrm{UV} / \mathrm{V}$ is was used, at $25^{\circ} \mathrm{C}, \lambda=340$ $\mathrm{nm}\left(\varepsilon=5.70 \mathrm{mM}^{-1} \mathrm{~cm}^{-1}\right.$, for LDH and $\varepsilon=6.93 \mathrm{mM}^{-1} \mathrm{~cm}^{-1}$ for $\left.\mathrm{MDH}\right)$.

\subsubsection{AChE extraction and activity}

The brain was homogenized in a Potter-Elvehjen homogenizer, with $0.1 \mathrm{M}$ Tris-HCl buffer $(\mathrm{pH} 7.4)$ containing $0.1 \%$ Triton $\mathrm{X}-100$ in the proportion $1: 12.5(\mathrm{w} / \mathrm{v})$ of tissue:buffer. The homogenate was sonicated (Model 100, Fisher Scientific) and then centrifuged at 14,000 x g (5810 R, Eppendorf) for 10 minutes at $4^{\circ} \mathrm{C}$, and the supernatant was used for determination of AChE activity. The reaction mixture contained $24 \mathrm{mM}$ Tris- $\mathrm{HCl}$ buffer (pH 7.4), $1 \mathrm{mM} \mathrm{CaCl} 2$ and $0.35 \mathrm{mM} 5,5^{\prime}$-dithiobis-2-dinitrobenzoic acid (DTNB) and the diluted sample (Bonacci et al., 2009). The reaction was started by adding $2 \mathrm{mM}$ acetylthiocholine. The absorbance was determined at $405 \mathrm{~nm}\left(\varepsilon=13.3 \mathrm{mM}^{-1} \mathrm{~cm}^{-1}\right)$ (Weber apud Eyer et al. (2003) by using a Beckman DU640 spectrophotometer maintained at $25^{\circ} \mathrm{C}$ by the Peltier system. AChE activity was expressed in $\mu \mathrm{mol}$ of substrate transformed into product per minute (U). Activities were calculated as a function of total protein concentration and expressed as $\mathrm{U} \mathrm{mg}^{-1}$ protein. Total protein was determined by the Bradford method (1976) using bovine serum albumin (BSA) as a standard.

\subsection{Data analysis}

Statistical analysis was done using GraphPad Prism for Mac, version 8.3.0. The results are presented as mean \pm SEM (standard error of the mean). Statistical comparison between the groups was done using one-way ANOVA, followed by the multiple pairwise Tukey comparison test. Differences were considered significant for $p<0.05$. The sample size is described in Table 1.

Table 1. Number of fish used for analysis.

\begin{tabular}{c|ccccccccc}
\hline \multirow{2}{*}{ Sampling site } & \multicolumn{4}{|c}{ Kidney } & \multicolumn{4}{c}{ Gills } & \multicolumn{3}{c}{ Brain } \\
\cline { 2 - 10 } & SOD & CAT & MDH & LDH & SOD & CAT & MDH & LDH & AChE \\
\hline P1 & 5 & 5 & 5 & 5 & 5 & 5 & 5 & 5 & 5 \\
P2 & 5 & 5 & 5 & 5 & 5 & 5 & 4 & 5 & 5 \\
P3 & 5 & 5 & 3 & 3 & 5 & 5 & 3 & 3 & 5 \\
\hline
\end{tabular}




\section{RESULTS AND DISCUSSION}

The results show that fish collected at P2 had lower levels of renal SOD when compared to fish from P3 (Figure 1A). The levels of CAT, MDH and LDH were similar in the three collection sites (Figure 1B, 1C and 1D). These results indicate that only SOD was sensible to environmental conditions present in $\mathrm{P} 2$.
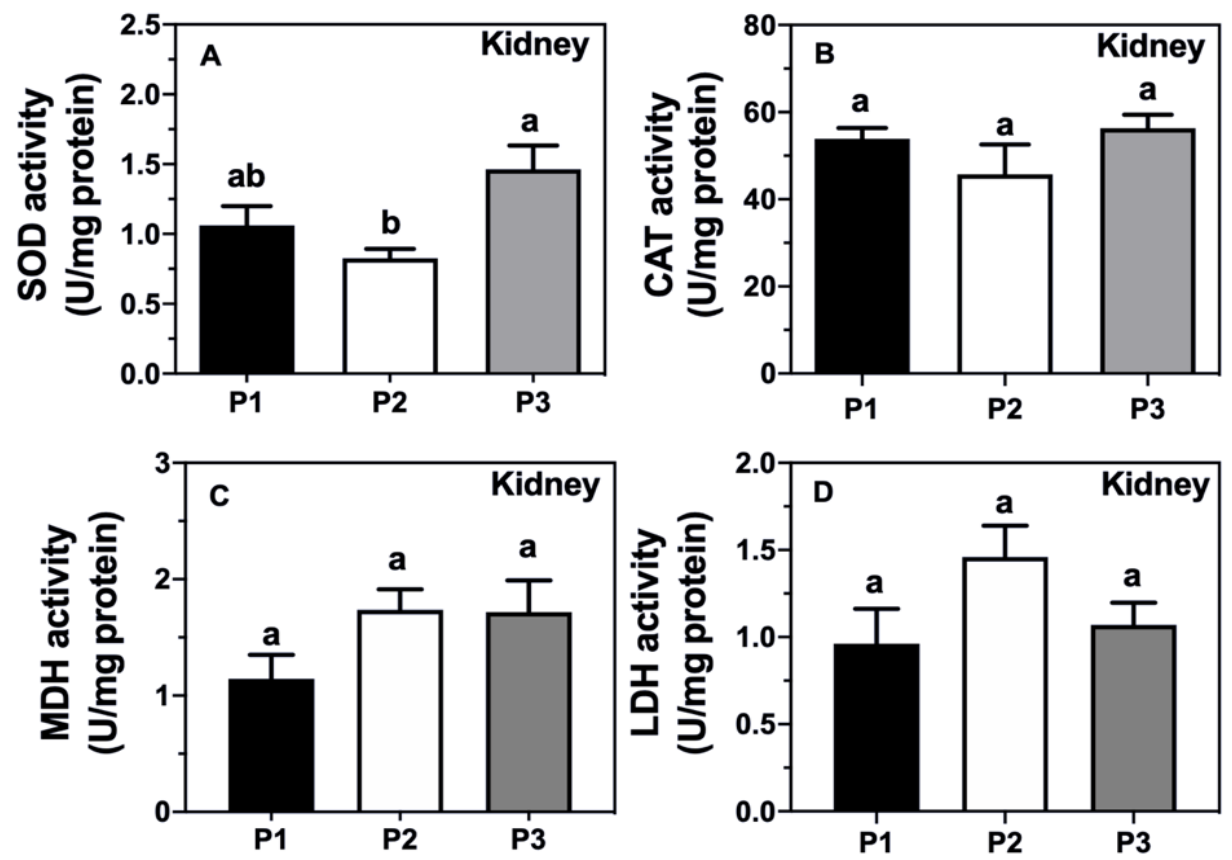

Figure 1. Activities (mean \pm SEM) of superoxide dismutase - SOD (A), catalase - CAT (B), malate dehydrogenase - MDH (C) and lactate dehydrogenase - LDH (D) from kidney of A. bimaculatus collected at 3 sites (P1, P2 and P3). Different letters above error bars indicate significant differences $(p<0.05)$.

The physicochemical analysis of the water of sites P1, P2 and P3 at the time of fish capture has already been published, as well as the map with the location of these sites (Batista et al., 2014, Ribeiro et al., 2015). These data from the physicochemical analyses indicated that: (1) the less impacted site was P1, although its total phosphate level $\left(0.3 \mathrm{mg} \mathrm{L}^{-1}\right)$ was slightly elevated in relation to reference values $\left(0.1 \mathrm{mg} \mathrm{L}^{-1}\right)$; (2) the conductivity of the $\mathrm{P} 2$ aquatic environment $\left(198.7 \mu \mathrm{S} \mathrm{cm}^{-1}\right)$ was 1.9 times higher than in $\mathrm{P} 1$, and 1.6 times higher than in $\mathrm{P} 3$, showing that $\mathrm{P} 2$ fish were exposed to high levels of electrolytes from an impacted environment (CETESB, 2009); (3) P3 presented the highest values of chemical oxygen demand (COD), indicating abundance of organic matter in the water.

The present study showed that specimens from the P2 site had lower levels of renal SOD, while lower levels of this enzyme occurred in gills in fish from P3. Batista et al. (2014) showed that the activity of hepatic SOD was higher in fish from P3, in comparison with that of P2. Therefore, SOD from liver, kidney or gills of $A$. bimaculatus could be used as a biomarker. Other suitable biomarkers are MDH from brain because the activity of brain MDH was elevated in fish from P3, as well as muscle MDH in fish from P2 (de Almeida et al., 2016). LDH from gills could also be a biomarker because the activity of gill LDH was lower in fish from P3, in comparison to those of P1 (Ribeiro et al., 2015).

The activities of CAT, MDH and LDH from kidney tissue were not influenced by the sites where the fish lived. Therefore, these enzymes are apparently not sensitive to environmental conditions present in $\mathrm{P} 1, \mathrm{P} 2$ and $\mathrm{P} 3$. 
Decreased levels of SOD activity in fish can be caused by chlorpyrifos, a broad-spectrum organophosphate insecticide (Kavitha and Rao, 2008). The activity of muscle MDH was elevated in P2 fish (de Almeida et al., 2016) and because MDH activity in fish can be increased by chlorpyrifos (Narra et al., 2015), the presence of this pesticide may be suspected in P2. Moreover, the activity of liver CAT is elevated in the fish from P2 (Batista et al., 2014), suggesting an increase of oxidative processes that CAT action aimed to neutralize in these specimens. However, chlorpyrifos and carbamates also inhibit fish AChE (Kavitha and Rao, 2008; Deb and Das, 2013) but this enzyme was not inhibited in the fish from P2. Although P2 is close to agricultural areas, and insecticides might be present there, it is possible that lower levels in kidney and liver SOD (present work and Batista et al., 2014), as well as the higher levels in muscle MDH (de Almeida et al., 2016) and liver CAT (Batista et al., 2014) were not caused by chlorpyrifos or carbamates.

SOD activity was lower in gills of $A$. bimaculatus from P3 in comparison with fish from $\mathrm{P} 1$, but CAT activity was not significantly affected by sampling sites (Figure 2).
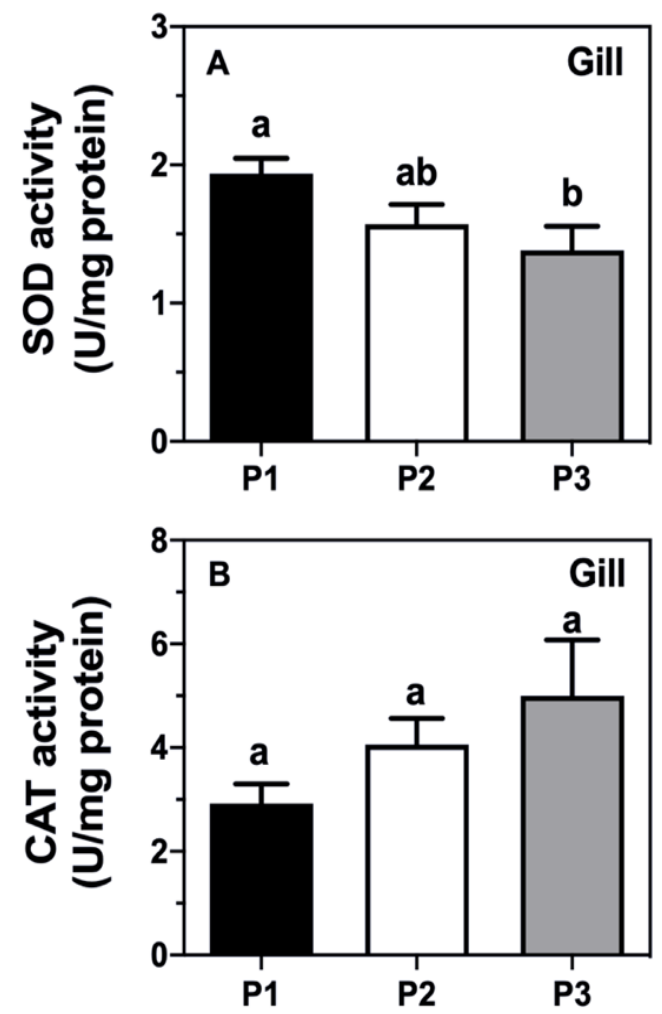

Figure 2. Activities (mean \pm SEM) of superoxide dismutase - SOD (A) and catalase - CAT (B), from gills of $A$. bimaculatus collected at 3 sites (P1, P2 and P3). Different letters above error bars indicate significant differences $(p<0.05)$.

The activities of $\mathrm{MDH}$ and $\mathrm{AChE}$ were higher in fish from $\mathrm{P} 3$ than in those from P1 (Figures. 3A and 3C). The activity of LDH was also the highest in the fish from P3, however, the difference was not statistically different in comparison with fish from P1 or P3 (Figure. 3B).

Attempts to determine SOD and CAT activities in brain tissue were done using the methods described in the Material and Methods section; however, the results were inconsistent, and these methods are not suitable for determination of SOD and CAT from brain tissues of $A$. bimaculatus. 

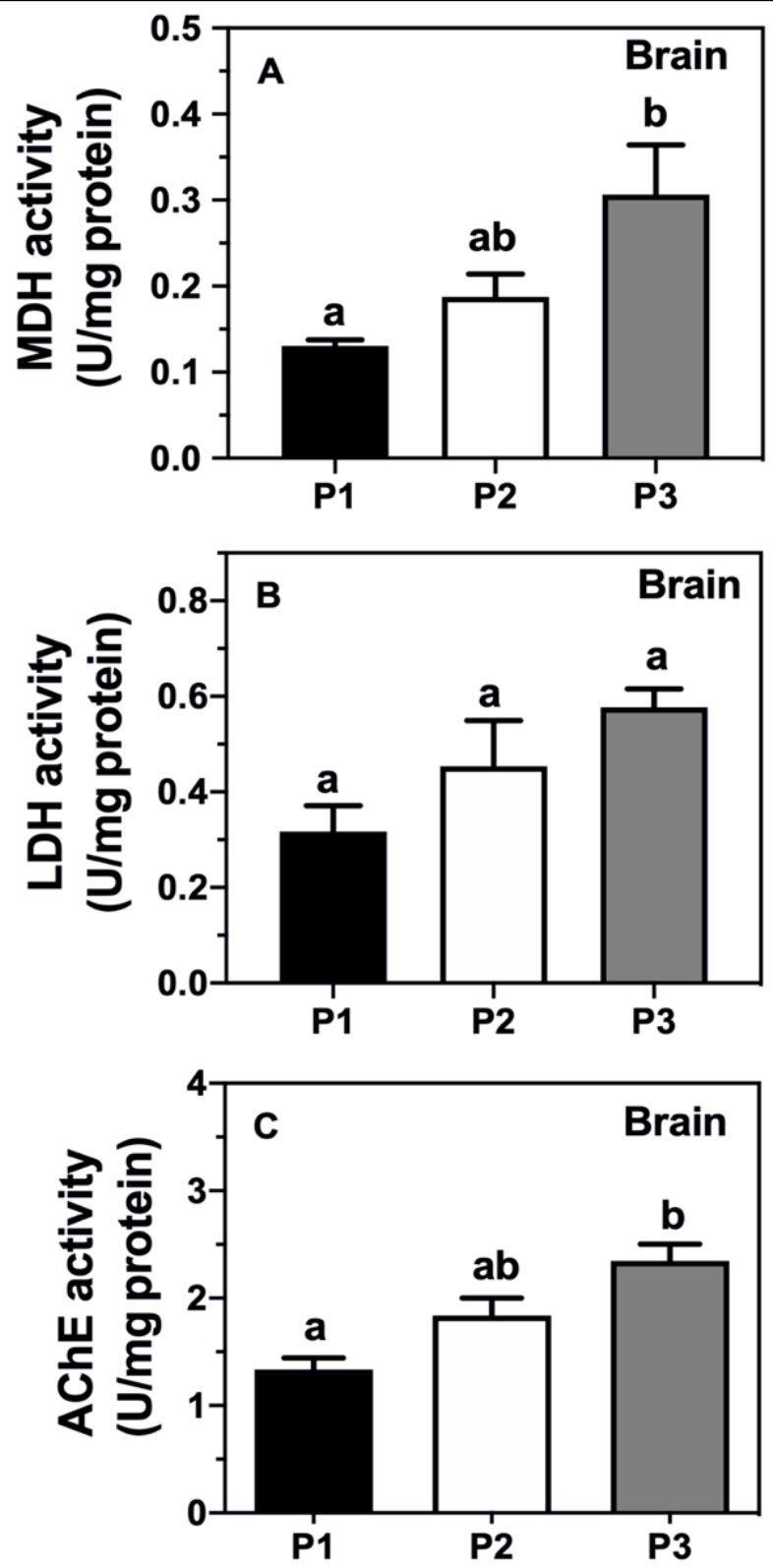

Figure 3. Activities (mean \pm SEM) of malate dehydrogenase - MDH (A), lactate dehydrogenase - LDH (B) and Acetyl cholinesterase - AChE (C) from brain tissue of $A$. bimaculatus collected at 3 sites ( $\mathrm{P} 1, \mathrm{P} 2$ and $\mathrm{P} 3$ ). Different letters above error bars indicate significant differences $(p<0.05)$.

The levels of MDH and AChE of brain tissue were elevated in the fish from P3 in comparison with P1. Moreover, Batista et al. (2014) also found increased levels of liver CAT in the fish from P3 when compared to P1. Levels of SOD and LDH from gill tissue were lower in P3 in comparison with P1 (present work and Ribeiro et al. (2015)), and we conclude that environmental conditions in P3 also caused several changes in enzyme levels. However, the nature of the contaminants that specifically causes these modifications is still uncertain. Nevertheless, metal ions in water, such as aluminum and manganese decreased the activity of gill SOD of Astyanax altiparanae (Abdalla et al., 2019). The activity of brain AChE increased in the fish Danio rerio exposed to aluminum for $96 \mathrm{~h}$ at $\mathrm{pH} 5.8$ (Senger et al., 2011). Activity of MDH from porcine heart was also increased by aluminum (Yang et al., 2011). 
Further analysis of water from P1, P2 and P3 was done in December 2016. The water collected at these sites was analyzed in the laboratory of SABESP (Laboratório da Divisão de Controle Sanitário - Vale do Paraíba, SABESP - Companhia de Saneamento Básico do Estado de São Paulo), located at Rua Paulo Setúbal, 19, Vila Adyanna, São José dos Campos, S.P.

Although the water composition changes continuously and the results of these analysis cannot be used to explain the enzyme activities presented in this work, they can indicate lines for future investigations. The concentration of 51 organic compounds were analyzed in waters from the three places (Table 2). The level of all compounds were lower than the maximum admissible concentration established by CONAMA Resolution 357 (Brasil, 2005) for Class I water.

Table 2. Organic compounds quantified in waters from sites P1, P2 and P3 in December 2016. The concentration $\left(\mu \mathrm{g} \mathrm{L}^{-1}\right)$ of each compound is shown in parentheses and the values were the same in waters from the three places.

\begin{tabular}{|c|c|c|}
\hline Compound $\left(\mu \mathrm{g} \mathrm{L}^{-1}\right)$ & Compound $\left(\mu \mathrm{g} \mathrm{L}^{-1}\right)$ & Compound $\left(\mu \mathrm{g} \mathrm{L}^{-1}\right)$ \\
\hline Acrylamide $(<0.1)$ & Endrin $(<0.001)$ & Simazine $(<0.02)$ \\
\hline Alachlor $(<0.05)$ & Ethylbenzene $(<0.48)$ & Styrene $(<1.28)$ \\
\hline Aldrin+Dieldrin $(<0.001)$ & Glyphosate $(<8.0)$ & Surfactants $(<0.05)$ \\
\hline Atrazine $(<0.05)$ & Gution $(<0.005)$ & Tetrachloroethene $(<0.48)$ \\
\hline Benzene $(<0.44)$ & $\begin{array}{l}\text { Heptachlor+Heptachlor epoxide } \\
(<0.003)\end{array}$ & Toluene $(<1.24)$ \\
\hline Benzo[a]anthracene $(<0.01)$ & Hexachlorobenzene $(<0.001)$ & Trichlorobenzene $(<0.7)$ \\
\hline Benzo[a]pyrene $(<0.025)$ & Indene $[1,2,3-c d]$ pyrene $(<0.025)$ & Trichloroethene $(<0.51)$ \\
\hline Benzo[b]fluoranthene $(<0.01)$ & Lindane $(<0.005)$ & Trifluraline $(<0.01)$ \\
\hline Benzo[k]fluoranthene $(<0.025)$ & Malathion $(<0.05)$ & Xylenes $(<1.51)$ \\
\hline Carbon tetrachloride $(<1.03)$ & Metolachlor $(<0.05)$ & 1,1-Dichloroethene $(<0.72)$ \\
\hline Chlordane (isomers) $(<0.01)$ & Metoxychlor $(<0.01)$ & 1,2-Dichloroethane $(<1.95)$ \\
\hline Chrysene $(<0.01)$ & Monochlorobenzene $(<0.4)$ & 2-Chlorophenol $(<0.05)$ \\
\hline $\begin{array}{l}\text { DDT } \\
(\text { p,p'-DDT }+ \text { p,p'DDE }+ \text { p,p'DDD })(< \\
0.001)\end{array}$ & Parathion $(<0.01)$ & 2,4-Dichlorophenol $(<0.05)$ \\
\hline $\begin{array}{l}\text { Demeton (Demeton-O+Demeton-S) } \\
(<0.1)\end{array}$ & $\begin{array}{l}\text { PCBs (Polychlorinated biphenyls) } \\
(<0.0005)\end{array}$ & 2,4-Dichlorophenoxyacetic acid $(<0.1)$ \\
\hline Dibenzo[a,h]anthracene $(<0.01)$ & & $\begin{array}{l}2,4,5 \text {-Trichlorophenoxy acetic acid }(< \\
0.1)\end{array}$ \\
\hline $\begin{array}{l}\text { Dichloromethane } \\
(<0.66)\end{array}$ & $\begin{array}{l}\text { Pentachlorophenol } \\
(<0.05)\end{array}$ & $\begin{array}{l}\text { 2,4,5-Trichlorophenoxy propionic acid } \\
(<0.1)\end{array}$ \\
\hline $\begin{array}{l}\text { Endosulfan }(\mathrm{I}+\mathrm{II}+\text { sulfate }) \\
(<0.01)\end{array}$ & $\begin{array}{l}\text { Pentacyclodecane dodecachloride } \\
(<0.0005)\end{array}$ & $\begin{array}{l}\text { 2,4,6-Trichlorophenol } \\
(<0.1)\end{array}$ \\
\hline
\end{tabular}

Total coliforms were elevated (Table 3), but there are no limits for these in fresh waters. The count of Escherichia coli, a thermotolerant bacteria, was elevated in P1 and P3, suggesting that there may be fecal contamination at these sites. The limit of $E$. coli in water for recreational use is $800100 \mathrm{~mL}^{-1}$ (Brasil, 2000) and waters from P1 and P3 would be inappropriate for this purpose, and the water from $\mathrm{P} 3$ may be also inappropriate for use as drinking water for confined bred animals (Brasil, 2005). 
Table 3. Total coliforms and E. coli in the water from sites P1, P2 and P3 analyzed in December 2016.

\begin{tabular}{lccc}
\hline \multirow{2}{*}{ Coliforms } & \multicolumn{3}{c}{ Sampling sites } \\
\cline { 2 - 4 } & \multicolumn{3}{c}{ Count (most probable number $\left.100 \mathrm{~mL}^{-1}\right)$} \\
\cline { 2 - 4 } & 24196 & 24196 & 24196 \\
\hline Total coliforms & 920.8 & 183 & $1515^{*}$ \\
E. coli & & & P3 \\
* The limit of 1000 thermotolerant coliforms 100 $\mathrm{mL}^{-1}$ may not be exceeded in water \\
for confined bred animals in $>80 \%$ of 6 samples, collected every two months for 1 \\
year (Brasil, 2005).
\end{tabular}

The results for inorganic components of sampled water were analyzed and are shown in Table 4. Aluminum (Al) is considered insoluble at $\mathrm{pH} 6$ to 8 because it forms $\mathrm{Al}(\mathrm{OH})_{3}$ in this $\mathrm{pH}$ range, but episodes of rapid acidification due to events such as acidic rain and other ecological changes could solubilize the insoluble forms of $\mathrm{Al}$ in water, and this solubilized $\mathrm{Al}$ could be toxic for fish populations (Abdalla et al., 2019). On the other hand, when water $\mathrm{pH}$ increases and Al-solubility decreases in an acidic water body, Al starts to polymerize accumulating on the gill surface and causes toxicity in fish (Poléo et al., 2017). Determination of dissolved $\mathrm{Al}$ in waters from the three places was not performed, however, total aluminum in $\mathrm{P} 3$ was elevated (Table 4); therefore, the $\mathrm{pH}$ and dissolved $\mathrm{Al}$ should be monitored at these sites. Previous data indicate that $\mathrm{pH}$ from P1, P2 and P3 were 6.5, 6.4 and 6.2, respectively (Batista et al., 2014), indicating that $\mathrm{P} 3$ presented the most acid water among the sampling sites.

Total iron is elevated in P2. This metal is predominantly found as colloidal hydrous iron oxides that are not biologically available in freshwater or seawater. However, the reduction of the iron of $\mathrm{Fe}$ (III) oxyhydroxide colloids in reducing environments of anoxic zones or sediments slowly leaches Fe (II) to the water. The diet is probably most important source of iron in aquatic environments, but iron uptake also occurs by fish gills (Bury and Grosell, 2003). Physical clogging of gills and gill damage occurred during lethal and sublethal exposure to iron (Dalzell and Macfarlane, 1999).

P2 also presented high levels of manganese. The toxicity of manganese in fish depends on species and, within a species, depends on the tissue, and this metal decreased the activity of CAT and SOD in the brain of some species of fish (Vieira et al., 2012; Arndt et al., 2014).

\section{CONCLUSIONS}

Liver, gills, muscle and brain tissues of $A$. bimaculatus are good sources of enzymes to evaluate environmental impact in the Una River basin. Hepatic SOD and CAT, gill SOD and $\mathrm{LDH}$, muscle $\mathrm{MDH}$, and cerebral $\mathrm{MDH}$ and $\mathrm{AChE}$ were sensitive to different environmental conditions of the 3 sampling sites of the Una River basin. The main difference among these environments appears to be the composition of metal in water. Future studies should investigate the effect of the predominant metals in water on fish enzymes or enzymes of other organisms to monitor environmental risks for water ecosystems of the Una River basin. 
Table 4. Inorganic components of waters from sites P1, P2 and P3 in December 2016. The maximum admissible values refer to Class I water, intended for human consumption after simplified treatment, for protection of aquatic communities and for recreation as defined in CONAMA Resolution 357 (Brasil, 2005).

\begin{tabular}{|c|c|c|c|c|}
\hline \multirow{3}{*}{ Inorganic parameters } & \multirow{3}{*}{ Maximum admissible values (mg/L) } & \multicolumn{3}{|c|}{ Sampling sites } \\
\hline & & $\mathrm{P} 1$ & P2 & $\mathrm{P} 3$ \\
\hline & & \multicolumn{3}{|c|}{ Concentration $\left(\mathrm{mg} \mathrm{L}^{-1}\right)$} \\
\hline Aluminum (total) & Dissolved aluminum $=0.1 *$ & 0.33 & 0.08 & 1.40 \\
\hline Ammonia & $\mathrm{NE}^{* *}$ & 0.49 & 0.48 & 0.16 \\
\hline Antimony (total) & 0.005 & $<0.005$ & $<0.005$ & $<0.005$ \\
\hline Arsenic (total) & 0.01 & $<0.01$ & $<0.01$ & $<0.01$ \\
\hline Barium (total) & 0.7 & 0.04 & 0.29 & 0.05 \\
\hline Cadmium (total) & 0.001 & $<0.001$ & $<0.001$ & $<0.001$ \\
\hline Calcium (total) & $\mathrm{NE}$ & 7.67 & 16.79 & 8.98 \\
\hline Chloride & 250 & 5.25 & 8.25 & $<1$ \\
\hline Cooper (total) & 0.05 & $<0.01$ & $<0.01$ & $<0.01$ \\
\hline Chromium (total) & 0.05 & $<0.01$ & $<0.01$ & $<0.01$ \\
\hline Cyanide (free) & 0.005 & $<0.03$ & $<0.03$ & $<0.03$ \\
\hline Cyanide (total) & $\mathrm{NE}$ & $<0.03$ & $<0.03$ & $<0.03$ \\
\hline Fluoride & 1.4 & $<0.2$ & $<0.2$ & $<0.2$ \\
\hline Iron (total) & Dissolved iron $=0.3^{*}$ & 4.57 & 10.98 & 4.58 \\
\hline Lead & 0.001 & $<0.01$ & $<0.01$ & $<0.01$ \\
\hline Magnesium (total) & $\mathrm{NE}$ & 3.18 & 8.95 & 4.51 \\
\hline Manganese (total) & 0.1 & 0.17 & 5.16 & 0.12 \\
\hline Mercury (total) & 0.0002 & $<0.0002$ & $<0.0002$ & $<0.0002$ \\
\hline Nitrate & 10 & 0.75 & 0.11 & 0.22 \\
\hline Nitrite & 1 & 0.03 & $<0.01$ & $<0.01$ \\
\hline Selenium & 0.01 & $<0.005$ & $<0.005$ & $<0.005$ \\
\hline Silica & NE & 20.0 & 11.3 & 21.1 \\
\hline Sodium (total) & NE & 4.57 & 3.94 & 3.88 \\
\hline Sulfate & 250 & $<2$ & $<2$ & $<2$ \\
\hline Sulfide & 0.002 & $<0.02$ & $<0.02$ & $<0.02$ \\
\hline Zinc (total) & 0.18 & $<0.01$ & $<0.01$ & $<0.01$ \\
\hline
\end{tabular}

$*$ There are no reference values for total aluminum or total iron, only for dissolved forms in Brasil (2005).

** $\mathrm{NE}=$ not established in Brasil (2005).

\section{ACKNOWLEDGMENTS}

The authors acknowledge SABESP for the water analysis presented in this paper.

Maria Tereza Oliveira Batista and Marilia Elias de Almeida received a research initiation scholarship PIBIC/CNPq, process numbers IBB_23_2013 and IBB_019_2016, respectively.

\section{REFERENCES}

ABDALLA, R. P. et al. Exposure to aluminum, aluminum + manganese and acid $\mathrm{pH}$ triggers different antioxidant responses in gills and liver of Astyanax altiparanae (Teleostei: Characiformes: Characidae) males. Comparative Biochemistry and Physiology Part C: Toxicology \& Pharmacology, v. 215, p. 33-40, 2019. http://www.sciencedirect.com/science/article/pii/S1532045618301340 
ARNDT, A.; BORELLA, M. I.; ESPÓSITO, B. P. Toxicity of manganese metallodrugs toward $\begin{array}{llllll}\text { Danio rerio. Chemosphere, v. 96, p. 46-50, } 2014 . & \end{array}$ http://www.sciencedirect.com/science/article/pii/S0045653513009983

BATISTA, M. T. O. et al. Tissue levels of the antioxidant enzymes superoxide dismutase and catalase in fish Astyanax bimaculatus from the Una River Basin. Revista Ambiente \& Água, Taubaté, v. 9, n. 4, p. 621-631, 2014. http://dx.doi.org/10.4136/ambi-agua.1473

BONACCI, S.; CORSI, I.; FOCARDI, S. Cholinesterases in the Antarctic scallop Adamussium colbecki: Characterization and sensitivity to pollutants. Ecotoxicology and $\begin{array}{lllllll}\text { Environmental Safety, v. 72, n. 5, p. 1481-1488, } 2009 . & \text {. }\end{array}$ http://www.sciencedirect.com/science/article/pii/S0147651309000037

BRADFORD, M. M. A rapid and sensitive method for the quantitation of microgram quantities of protein utilizing the principle of protein-dye binding. Analytical Biochemistry, v. 72, n. $1, \quad$ p. 248-254, 1976. http://www.sciencedirect.com/science/article/pii/0003269776905273

BRASIL. Ministério do Meio Ambiente. Conselho Nacional do Meio Ambiente. Resolução n. 274, de 29 de novembro de 2000. DOU nº 018, de 08/01/2001, págs. 70-71, 2000. Available at: < http://www2.mma.gov.br/port/conama/legiabre.cfm?codlegi=272 > Access in: November 2019.

Ministério do Meio Ambiente. Conselho Nacional do Meio Ambiente. Resolução n. 357, de 17 de março de 2005. Available at : <http://www.mma.gov.br/port/conama/legiabre.cfm?codlegi=459> Access in : September 2014.

BURY, N.; GROSELL, M. Iron acquisition by teleost fish. Comparative Biochemistry and Physiology Part C: Toxicology \& Pharmacology, v. 135, n. 2, p. 97-105, 2003. https://doi.org/10.1016/S1532-0456(03)00021-8

CETESB-COMPANHIA AMBIENTAL DO ESTADO DE SÃO PAULO. Apêndice A significado ambiental e sanitário das variáveis de qualidade das águas e dos sedimentos e metodologias analíticas e de amostragem. In: Qualidade das águas interiores no estado de São Paulo: Série Relatórios. Governo do Estado de São Paulo, Secretaria do Meio Ambiente. 2009. Available at: <https://cetesb.sp.gov.br/aguasinteriores/publicacoes-e-relatorios/ > Access in: November 2019

CHILDRESS, J. J.; SOMERO, G. N. Depth-related enzymic activities in muscle, brain and heart of deep-living pelagic marine teleosts. Marine Biology, v. 52, n. 3, p. 273-283, 1979. http://dx.doi.org/10.1007/BF00398141

ČOLOVIĆ, M. B. et al. Acetylcholinesterase inhibitors: pharmacology and toxicology.

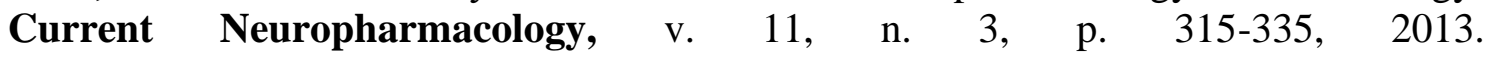
http://www.ncbi.nlm.nih.gov/pmc/articles/PMC3648782/

DALZELL, D. J. B.; MACFARLANE, N. A. A. The toxicity of iron to brown trout and effects on the gills: a comparison of two grades of iron sulphate. Journal of Fish Biology, v. 55, n. 2, p. 301-315, 1999. http://dx.doi.org/10.1111/j.1095-8649.1999.tb00680.x

de ALMEIDA, M. E. et al. Atividade da malato desidrogenase muscular de Astyanax bimaculatus da bacia hidrográfica do rio Una como biomarcadora de impacto ambiental. Revista Ambiente \& Água, v. 11, p. 1096-1108, 2016. http://dx.doi.org/10.4136/ambiagua. 1898 
DEB, N.; DAS, S. Chlorpyrifos toxicity in fish: a review. Current World Environment, v. 8, n. 1, p. 77, 2013. http://dx.doi.org/10.12944/CWE.8.1.17

EYER, P. et al. Molar absorption coefficients for the reduced Ellman reagent: reassessment. Analytical biochemistry, v. 312, n. 2, p. 224-227, 2003. https://doi.org/10.1016/S00032697(02)00506-7

HONORIO, J. R.; MARTINS, I. A. Ichthyofauna of the Una river in the Paraíba do Sul Paulista River Valley, Southeastern of Brazil. Biota Neotropica, v. 18, n. 4, 2018. http://dx.doi.org/10.1590/10.1590/1676-0611-bn-2018-0528

KAVITHA, P.; RAO, J. V. Toxic effects of chlorpyrifos on antioxidant enzymes and target enzyme acetylcholinesterase interaction in mosquito fish, Gambusia affinis. Environmental Toxicology and Pharmacology, v. 26, n. 2, p. 192-198, 2008/09/01/ 2008. http://www.sciencedirect.com/science/article/pii/S1382668908000537.

KONO, Y. Generation of superoxide radical during autoxidation of hydroxylamine and an assay for superoxide dismutase. Archives of Biochemistry and Biophysics, v. 186, n. 1, p. 189-195, 1978. http://www.sciencedirect.com/science/article/pii/0003986178904794

KROON, F.; STRETEN, C.; HARRIES, S. A protocol for identifying suitable biomarkers to assess fish health: A systematic review. Plos One, v. 12, n. 4, p. e0174762, 2017. https://doi.org/10.1371/journal.pone.0174762

KUMAR, N. et al. Cellular stress and histopathological tools used as biomarkers in Oreochromis mossambicus for assessing metal contamination. Environmental $\begin{array}{llllll}\text { Toxicology and Pharmacology, v. 49, p. 137-147, } 2017 . & \end{array}$ http://www.sciencedirect.com/science/article/pii/S1382668916303155

NARRA, M. R. et al. The role of vitamin $\mathrm{C}$ as antioxidant in protection of biochemical and haematological stress induced by chlorpyrifos in freshwater fish Clarias batrachus. $\begin{array}{lllll}\text { Chemosphere, } & \text { v. } & 132, & \text { p. } & 172-178,\end{array}$ http://www.sciencedirect.com/science/article/pii/S0045653515002064

NELSON, D. L.; COX, M.M. Princípios de bioquímica de Lehninger. $6^{\text {a }}$ edição. Porto Alegre: Artmed Editora, 2014. 1298 p.

POLÉO, A. B. S. et al. The high tolerance to aluminium in crucian carp (Carassius carassius) is associated with its ability to avoid hypoxia. PLOS ONE, v. 12, n. 6, p. e0179519, 2017. https://doi.org/10.1371/journal.pone.0179519

REGOLI, F. et al. Biochemical characterization of the antioxidant system in the scallop Adamussium colbecki, a sentinel organism for monitoring the Antarctic environment. Polar Biology, v. 17, n. 3, p. 251-258, 1997. https://doi.org/10.1007/s003000050129

RIBEIRO, A. C. et al. Atividades de lactato desidrogenase e malato desidrogenase de Astyanax bimaculatus (lambari) da bacia hidrográfica do rio Una como biomarcadoras de impacto ambiental. Revista Ambiente \& Água, Taubaté, v. 10, n. 4, p. 793-803, 2015. http://dx.doi.org/10.4136/ambi-agua.1615

SENGER, M. R. et al. Aluminum exposure alters behavioral parameters and increases acetylcholinesterase activity in zebrafish (Danio rerio) brain. Cell Biology and Toxicology, v. 27, n. 3, p. 199-205, Jun 2011. https://doi.org/10.1007/s10565-011-9181$\mathrm{y}$ 
SMITH, P. K. et al. Measurement of protein using bicinchoninic acid. Analytical $\begin{array}{lllllll}\text { Biochemistry, } & \text { v. } & 150, & \text { n. } & 1, & \text { p. } & 76-85,\end{array}$ http://www.sciencedirect.com/science/article/pii/0003269785904427

THUESEN, E. V.; MCCULLOUGH, K. D.; CHILDRESS, J. J. Metabolic enzyme activities in swimming muscle of medusae: is the scaling of glycolytic activity related to oxygen availability? Journal of the Marine Biological Association of the United Kingdom, v. 85, n. 03, p. 603-611, 2005. http://dx.doi.org/10.1017/S0025315405011537

VIEIRA, M. C. et al. Acute toxicity of manganese in goldfish Carassius auratus is associated with oxidative stress and organ specific antioxidant responses. Ecotoxicology and $\begin{array}{llllll}\text { Environmental } & \text { Safety, } & \text { v. } & 78, & \text { p. }\end{array}$ http://www.sciencedirect.com/science/article/pii/S0147651311004131

YANG, X. et al. Effects of Al(III) and nano-Al13 species on malate dehydrogenase activity. Sensors, Basel (Switzerland), v. 11, n. 6, p. 5740-5753, 2011. https://www.ncbi.nlm.nih.gov/pubmed/22163924 